\title{
De første idrætskvinder i Vejle før 2. verdenskrig
}

\author{
af Torben Jakobsen
}

Denne artikel er et resultat af en studiekreds om idrætshistorie i Vejle, afholdt i efteråret 1984. Studiekredsen var - sammen med placeringen af udstillingen ,,Sport i Vejle“ på Den Jyske Idrætsskole - første trin i etableringen af et lokalt idrætshistorisk aktivitetscenter i Vejle, formidlet gennem et samarbejde mellem Den Jyske Idrætsskole og Vejle Kulturhistoriske Museum. Vi håber senere at kunne fortsætte etableringsarbejdet med følgende trin: Etablering af faste studiekredse, systematisk indsamling af idrætshistorisk materiale og grundige undersøge/ser af idrættens udviklingshistorie i Vejle. Et første hovedmål er desuden udgivelse af en bog om ,,Sport i Vejle gennem 100 år ".

Foreløbigt er det blevet til en kronik i Vejle Amts Folkeblad den 15.6.85 (et sammendrag af nærværende artikel) og et „,blåt stempel“ fra Kulturministeriet, i form af en støttebevilling til de fysiske rammer på kr. 25.000,-. Dette beløb rækker dog ikke langt, f.eks. vil alene bevaringen af et stort historisk filmmateriale fundet på Den Jyske Idrætsskole, kræve langt større midler.

I efteråret 1985 vil det derfor blive forsøgt at få lokale idrætsorganisationer, foreninger og myndigheder til at støtte oprettelsen af det idrætshistoriske aktivitetscenter økonomisk, så en fuldtidsmedarbejder kan ansættes i 1986.

Det stod hurtigt studiekredsdeltagerne klart, at vi måtte vælge et tværgående idrætshistorisk tema, for på overkommelig tid at kunne lave et snit gennem den omfattende idrætshistorie i Vejle. Materialet, der stod til rådighed, var afleverede arkivalier (forhandlingsprotokoller, scrapbøger, billeder, jubilæumsskrifter m.m.), beliggende i Vejle Byhistoriske Arkiv, samt naturligvis lokale aviser tilbage $i$ tiden. Af disse kan nævnes den endnu eksisterende Vejle Amts Folkeblad, og de hedengangne: Vejle Amts Avis og Vejle Socialdemokrat, sidstnævnte kendt under skiftende navne som: Frit Folk og Jysk Aktuelt.

Som tema valgte vi et ofte overset område i idrætshistorien: De første kvinders indmarch $\mathrm{i}$ idrætten. Vi afgrænsede undersøgelsen til perioden før 2. verdenskrig, og opstillede en række ambitiøse arbejdsspørgsmål: 
- hvornår begyndte kvinderne i Vejle at dyrke idræt?

- hvilke idrætsgrene foretrak de?

- hvor mange blev ledere og trænere?

- hvordan reagerede mændene i foreningerne?

- hvilke roller fik kvinderne i foreningerne?

- blev kvinderne undertrykt af den mandsdominerede idræt?

Da vi desværre ikke havde ressourcer til at gennemføre nye indsamlinger, (herunder interviews med gamle irætsledere og aktive), var vi henvist til udelukkende at benytte det ovenfor nævnte arkivmateriale.

D.v.s. at denne artikel ikke besvarer alle de opstillede spørgsmål om de første idrætskvinder i Vejle; jeg kan kun give en første oversigt - og forhåbentligt pege på nogle tendenser ved kvindernes indmarch $\mathrm{i}$ Vejles idrætsliv.

Det skal endelig bemærkes, at alle anførte citater er omskrevet til moderne retskrivning.

\section{De første idrætskvinder i Danmark}

For at sætte de lokale idrætshistoriske tendenser $i$ Vejle ind $i$ en større forståelsesmæssig ramme, vil jeg gennem 2 oversigter give et indtryk af hvornår - og i hvilke discipliner - de første idrætskvinder generelt kunne accepteres. Vi starter med at se på kvindernes deltagelse i de moderne olympiske lege, der blev startet i 1896. Kvinder fik adgang til konkurrencerne første gang i 1900 i tennis. Derefter fulgte svømning (1912), fægtning (1924), gymnastik og atletik (1928) samt kano/kajakroning (1948).

Det skal bemærkes, at kvinder ikke deltog i de officielle konkurrencer ved O.L. i 1904, og at den olympiske jubilæumsfest i Athen i 1906 ikke anerkendes som officielle olympiske lege. 
Oversigt 1: Antal kvindelige deltagere i Olympiske Lege 1896-1948

\begin{tabular}{lrcrr}
\hline & $\begin{array}{c}\text { Danske del- } \\
\text { tagere i alt }\end{array}$ & $\begin{array}{c}\text { Heraf dan- } \\
\text { ske kvinder }\end{array}$ & $\begin{array}{c}\text { Danske } \\
\text { kvinder } \\
\mathrm{i} \%\end{array}$ & $\begin{array}{c}\text { Alle kvinder } \\
\mathrm{i} \% \text { af samtli- } \\
\text { ge deltagere }\end{array}$ \\
\hline Ar & 3 & & & \\
1896 & 13 & 0 & 0 & 0 \\
1900 & 0 & 0 & 0 & 0,6 \\
1904 & 86 & 0 & 0 & 0 \\
1908 & 161 & 0 & 0 & 1,8 \\
1912 & 176 & 1 & 0,6 & 2,2 \\
1920 & 82 & 4 & 2,3 & 2,4 \\
1924 & 83 & 9 & 11,0 & 9,4 \\
1928 & 24 & 9 & 10,8 & 9,0 \\
1932 & 135 & 6 & 25,0 & 8,1 \\
1936 & 181 & 15 & 11,1 & 9,4 \\
1948 & 18 & 9,9 & \\
\hline
\end{tabular}

Kilde: L. Killanin og J. Rodda: The Olympic Games. London 1976.

C. Diem: Weltgeschichte des Sports I og II. Stuttgart 1971.

J. Idorn (red): Dansk Idræts-Forbund 1896-1971. Kbh. 1971.

Oversigten skal tages med et stort gran salt, da der foreligger modstridende oplysninger i litteraturen. Desuden problematiseres tendenser i oversigten af, at antallet af deltagere i høj grad afhænger af hvor legene blev afholdt. Det mest markante eksempel herpå er legene i 1932, der foregik i Los Angeles, hvorfor lande som Danmark sendte meget få deltagere, og kvindernes \%-del derved blev overraskende stor.

Med disse forbehold in mente viser oversigten, at kvinderne gradvist blev accepteret ved internationale konkurrencer, men dog først i betydende omfang i 1930'rne. De danske kvinder deltog i tennis, svømning og fægtning, samt fra 1948 også i kajakroning og atletik.

Det skal dog bemærkes, at danske kvinder tidligere end oversigten viser, vakte opsigt ved internationale idrætsstævner. Fem kvindelige roere fremkaldte sensation ved så tidligt som 1906 at ro præsentationsroning ved de uofficielle olympiske lege i Athen. Endnu større opmærksomhed vakte danske kvindelige gymnaster på turneer rundt i Europa i 1880'erne, samt under opvisninger ved de olympiske lege i 1906 og 1908.

I det hele taget var gymnastikken den første kvindeidræt af betydning herhjemme. Allerede fra 1838 blev der dyrket kvindegymnastik ved private institutter i København, og snart blev den udbredt til resten af landet.

I starten foregik der en blot og bar efterligning af mændenes præstationer, men fra 1920'erne, blev kvindernes gymnastikform selvstændiggjort, og 
hovedvægten lagt på æstetisk-rytmisk holdgymnastik. Stærkt medvirkende til denne udvikling var etableringen af en ren kvinde-gymnastikhøjskole (Snoghøj) i 1925.

Først langt senere begyndte de danske kvinder i større omfang at dyrke konkurrenceorienteret idrætsgymnastik, som den, der var med på det olympiske program fra 1928. Derfor er gymnastikken ikke med i følgende oversigt, som viser hvornår Dansk Idræts-Forbunds specialforbund begyndte at afholde danmarksmesterskaber for kvinder.

Jeg har $\mathrm{i}$ oversigten kun medtaget underretninger om kvinder inden for Dansk Idræts-Forbund (DIF), da de idrætsklubber i Vejle, der senere skal omtales, alle blev tilknyttet dette forbund før 2. verdenskrig.

Den anden landsdækkende idrætsorganisation, De Danske Skytteforeninger (fra 1930 opdelt i: De Danske Gymnastikforeninger samt De Danske Skytte- Gymnastik- og Idrætsforeninger), havde overvejende medlemstilknytning uden for de større bysamfund. Kvinderne dyrkede her fra starten udelukkende gymnastik, og fra midt i 30'rne desuden håndbold og svømning.

Oversigt 2: Arstal for første DIF-arrangerede Danmarksmesterskaber for kvinder

\begin{tabular}{|c|c|c|}
\hline Ärstal & Disciplin & Bemærkninger \\
\hline 1906 & Fægtning & $\begin{array}{l}\text { Kvinderne deltog i fægtekonkurrencer i København } \\
\text { allerede fra } 1880 \text { 'erne. }\end{array}$ \\
\hline 1908 & Tennis & $\begin{array}{l}\text { Samme tidlige accept fandt sted i tennis. Første } \\
\text { danske kvindedeltager ved O.L. var i øvrigt tennis- } \\
\text { spilleren T. Sophy Castenschiold, der vandt sølv } \\
\text { Stockholm i } 1912 \text {. }\end{array}$ \\
\hline 1919 & Svømning & $\begin{array}{l}\text { Kvinder deltog første gang i svømmekonkurrence } \mathrm{i} \\
1899 \text {, men de måtte bære adskillige klædningsstyk- } \\
\text { ker for ikke at forarge den offentlige moral. Des- } \\
\text { uden måtte de under hele konkurrencen blive } \\
\text { vandet, samt optræde anonymt for at undgå gen- } \\
\text { kendelse og senere chikane. Denne anonymitet hos } \\
\text { kvindelige svømmere blev opretholdt til omkring } \\
1905 \text {. }\end{array}$ \\
\hline 1917 & Skøjteløb & $\begin{array}{l}\text { Den første gang foreningsorganiseret kvindelig } \\
\text { idrætsdeltagelse bemærkes, er ved skøjteløb arran- } \\
\text { geret af Skøjteløberforeningen i København i } 1869 \text {. } \\
\text { Der var dog ikke tale om egentlig idræt, snarere } \\
\text { stilfulde selskaber forlagt til skøjtebanen, idet kvin- } \\
\text { derne under løbet overholdt alle etikettens bud om } \\
\text { dannet påklædning, opførsel m.m. }\end{array}$ \\
\hline 1918 & Hockey & $\begin{array}{l}\text { Hockey blev fra } 1901 \text { dyrket i København, med hold } \\
\text { bestående af } 4 \text { kvinder og } 7 \text { mænd - spillet blev } \\
\text { (som senere badminton) betragtet som en ,,forlo- }\end{array}$ \\
\hline
\end{tabular}


velsesidræt". Danmarksturneringen for rene kvindehold kulminerede i 1933 og blev afholdt for sidste gang i 1962.

Allerede i 1880'erne blev der stiftet særlige kvinderoklubber. De kvindelige roere måtte kæmpe hårdt mod anklager for at drive ,uskøn og ukvindelig sport", hvorfor de i 1920 'rne følte sig tvunget til at indføre stilroning i stedet for kaproning, d.v.s. ikke den hurtigste båd, men den ,kønnest roede" skulle vinde! Denne ,ææstetiske roning blev dog opgivet igen i 1935.

$\begin{array}{ll}1931 & \begin{array}{l}\text { Badminton og } \\ \text { golf }\end{array} \\ 1932 & \text { Ridning } \\ 1938 & \text { Håndbold } \\ 1941 & \begin{array}{l}\text { Roning (firer } \\ \text { med styrmand) }\end{array} \\ 1944 & \text { Atletik }\end{array}$

Kvindehåndbold blev dyrket ved enkelte skoler fra o. 1908. Den første turnering blev afviklet i 1926.

Efter enkelte forsøg i 1899 (traveture) og i 1909 (løb), var kvinderne første gang med ved et atletikstævne på Østerbro i København i 1922.

Danmarksrekorder blev anerkendt fra 1930.

Kilde: J. Idorn (red): DIF 1896-1971. Kbh. 1971.

J. Clausen og T. Krogh (red): Danmark i fest og glæde. Bd. 5-6. Kbh. u.å.

H. Skougaard: Sporten gennem 100 år. Kbh. 1978.

Festskrift for Dansk Forening for Rosport. Kbh. 15.1.1937.

\section{Modstanden mod idrætskvinderne}

Det er ofte blevet fremhævet, at de afgørende årsager til, at kvinderne meget senere end mændene begyndte at dyrke organiseret idræt, må søges i det traditionelle kønsrollemønster, som ikke levner kvinderne megen fritid, samt i de medicinske fordomme om kvindens skrøbelige legeme og nervøse gemyt, der ikke tåler idrættens (specielt konkurrencernes) udmattelse og ophidselse. Disse 2 faktorer: Den manglende fritid og de lægeanførte råd om at undgå idrætsudøvelse, kan langt hen ad vejen forklare hvorfor så få kvinder dyrkede idræt i starten af århundredet, men ikke hvorfor de første kvinder valgte (eller blev accepterede af mændene i) netop de idrætsgrene, som fremgår af de to oversigter: Fægtning, svømning, tennis, gymnastik og skøjteløb. Årsagerne hertil må sandsynligvis findes i tidens almindelige syn på kvinden: Hun skulle være sømmeligt klædt for ikke at forarge den offentlige moral - og hun skulle beskæftige sig med feminine gøremål for ikke at blive betragtet som ukvindelig. Disse to hovedkrav til kvinden skinner 
ofte igennem, når man studerer hvordan de første idrætskvinder blev modtaget af mændene $\mathrm{i}$ idrætsforeningerne - og af pressen.

Som eksempel herpå kan anføres et interview i Vejle Amts Folkeblad den 07.05.1932 med den daværende formand for Vejle Idræts Forening, Ch. Christensen (C. C.), i anledning af VIF's 25 års jubilæum:

Int.: „Hvor mange damer har De i foreningen?

C. C.: En 35 stykker.

Int:: Flirter de ikke med mændene?

C. C.: Ikke under idrætten i hvert fald - nej så hænger de skam i ... vi har tidligere haft damer i klubben, men de tog ikke sporten alvorligt nok, de holdt mere af at filme. Men de unge piger vi har hos os nu, har jeg kun lovord for.

Int.: Er atletik egentlig dameidræt?

C. C.: Ja det synes jeg. De må huske på, at der kun er tale om lette rekvisitter og mindre afstande under løbene, så det ikke virker udmattende“".

Når en sådan mistænksom holdning til idrætskvinderne holdt sig langt op i dette århundrede, kan det ikke overraske, at kvinderne i første række gjorde sig bemærket, og blev accepteret, i idrætsgrene, hvor de kunne være sømmeligt påklædt (ikke lægge op til at ,filme med mændene“) og agere på en kvindelig måde. Svømning adskilte sig dog til en vis grad fra dette mønster, men som nævnt i oversigt 2, foretrak de første kvindelige svømmere derfor også at optræde anonymt.

Det generelle syn på kvinden ændredes gradvist; hun blev efterhånden accepteret som en almindelig borger og udstyret med de rettigheder dette indebar: I 1909 fik kvinder valgret til kommunale råd, i 1915 valgret til Rigsdagen, og desuden kom der i perioden 1922-26 forskellige love om ægteskabelig ligestilling mellem kønnene. Den første kvindelige minister (Nina Bang, Socialdemokratiet) blev i øvrigt udnævnt i 1924.

Disse resultater skyldtes at der blev ført en omfattende kamp for kvindernes rettigheder - en kamp, der også havde virkninger inden for idrætten: Fra 1918 kunne kvinder formelt (reelt var det sket langt tidligere) optages som medlemmer af De Danske Skytteforeninger, og den første kvinde blev valgt til organisationens ledelse i 1923.

Inden for Dansk Idræts-Forbund accepteredes kvinderne efterhånden i en sådan grad, at de 4 første blev valgt til bestyrelsen i 1921.

Det lykkedes dog aldrig - heller ikke i vor tid - kvinderne at få en repræsentation i ledelsen af idrættens organisationer, som svarede til deres 
andel af de aktive medlemmer. F.eks. udgjorde kvinderne i 1982-83 ca. $36 \%$ af DIF's aktive medlemmer, mens der kun var en kvinde (ud af 84) i DIF's bestyrelse, og ingen i forretningsudvalget, der består af 11 mænd.

\section{Kvindeidræt i Vejle før-og omkring århundredskiftet}

Som det gjaldt på landsplan, er skøjteløb den første foreningsorganiserede kvindeidræt, det er lykkedes at finde oplysninger om i Vejle.

I en medlemsbog fra ,Vejle Skøjteløberforening “, omhandlende vintersæsonen 1888-1889, er der med navns nævnelse anført 40 kvindelige medlemmer. (Desuden 63 mandlige og 94 børn).

Endvidere bliver det i gamle udgaver af „,Vejle Vejviser" oplyst, at formanden for Vejle Skøjteløberforening fra århundredskiftet og frem til foreningens opløsning i 1909 hed H. West. Men hermed er også alt hvad det er lykkedes os at finde frem til om de første idrætskvinders forening i Vejle refereret.

Efter skøjteløberne fulgte ret hurtigt kvindelige tennisspillere. Fra en artikel i Vejle Amts Folkeblad den 04.04.1900, ved vi, at Vejle Lawn Tennisklub blev stiftet den 03.04.1900. Til bestyrelsen blev, foruden 3 mænd, valgt: Frk. J. Bjerregaard og frk. J. Brincker. Det oplyses ikke hvor mange medlemmer klubben havde ved stiftelsen, men dog at alle (både mænd og kvinder) havde dyrket sporten i ,,nogen tid" forud for starten i 1900.

Det fremgår desuden af den første forhandlingsprotokol, at klubben kaldte sig Vejle $\mathrm{Ny}$ Lawn Tennisklub i starten, angiveligt fordi der tidligere havde eksisteret en tennisklub med bane i Teglgraven (hvor der i 1930'rne blev etableret tennis- og badmintonhal), men om der også var kvinder med $i$ denne første tennisklub i Vejle, vides desværre ikke. Det kan dog slås fast, at Vejle, ligesom København, så de første kvindelige tennisspillere før århundredskiftet.

Disse pionerer overholdt - ligesom de første skøjteløbere - under deres idræt alle traditionelle krav om feminin påklædning og opførsel. Først fra omkring 1908 kunne der i Vejle findes kvindelige tennisspillere, som drev deres'idræt på kraftfuld og præstationsorienteret vis.

\section{Kvindegymnastikken i Vejle.}

Den første idrætsform, som kvinderne i Vejle dyrkede i større og fast organiseret stil var - som så mange andre steder i Danmark - gymnastikken.

Foregangsforeningen på dette område var en af Vejles ældste idrætsforeninger, Vejle Gymnastikforening, der blev stiftet i 1888 under navnet: Vejle 


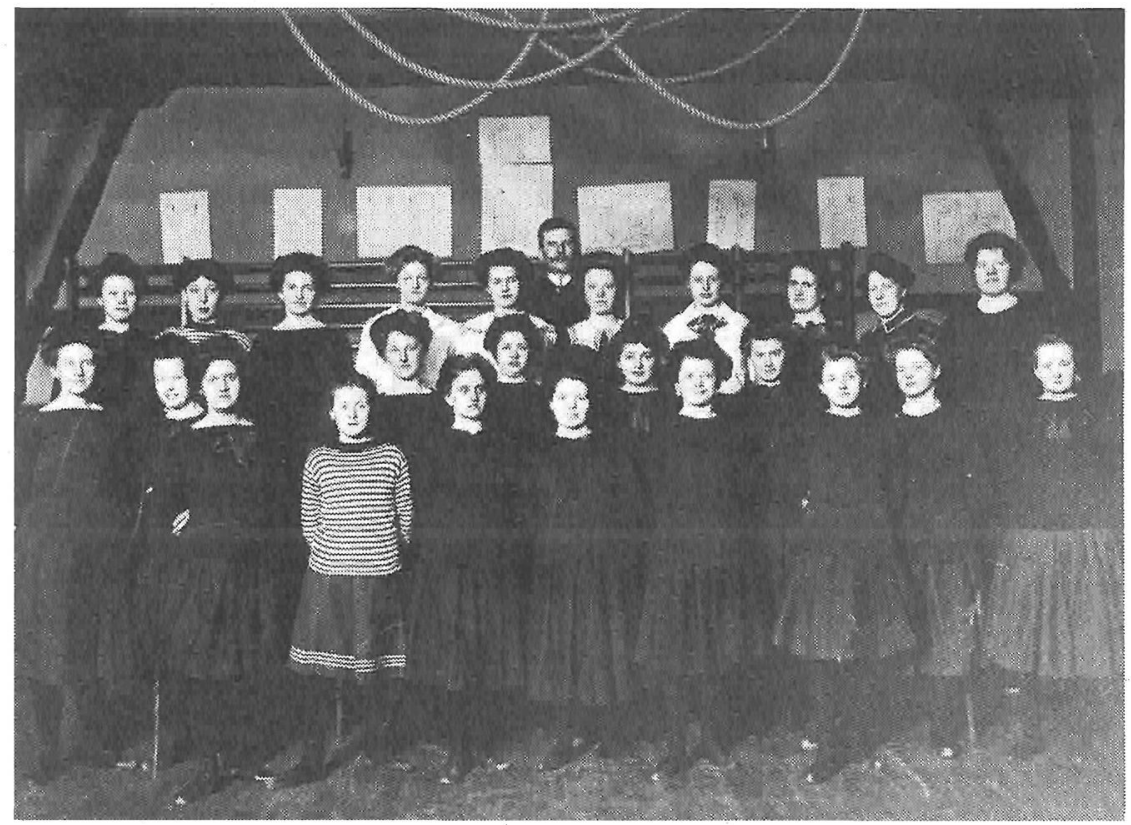

En af årsagerne til kvindegymnasternes tidlige anerkendelse fremgår af: Kvinderne benyttede absolut tækkelige klæder, der kun ,blottede “ ansigt og hænder. I baggrunden ses formanden for Vejle Gymnastik-Forening.

Gymnastiske Forening. Det bør dog nævnes, at der på dette tidspunkt fandtes en anden gymnastikforening i byen, nemlig „Frejr" (stiftet i 1885), men i denne kunne udelukkende håndværkere optages som medlemmer. De to foreninger blev i 1894 sluttet sammen under det nuværende navn: Vejle Gymnastik Forening (VGF). Foreningen har efterladt sig et omfattende arkiv, med forhandlingsprotokoller, billeder, 3 festskrifter m.m., så kvindegymnastikkens udvikling i VGF kan belyses forholdsvis grundigt.

På foreningens generalforsamlinger og bestyrelsesmøder i starten af dette århundrede blev det flere gange drøftet at optage kvindegymnastik på programmet. Dette ønske blev som regel afvist med, at der fandtes ,privat gymnastikundervisning" for kvinder andre steder i byen, som man ville komme i konkurrence med. (Det er desværre ikke lykkedes at få opklaret hvad denne betegnelse dækkede - eller hvor den ,private undervisning“" foregik). Denne betænkelighed fik stadig mindre vægt, og den 13.09.1907 blev det besluttet at oprette en afdeling for kvindegymnastik i VGF. Ved 
afslutningen af den første sæson - vinteren 1907-08 - meddeles det i foreningens protokol, at:

,,... dameholdet under frk. M. Gertz's ledelse, har bestået af ca. 30 elever, som er mødt flittigt og gået godt frem. Det gode resultat synes at love godt for denne gren af gymnastikforeningens virksomhed".

Kvinderne måtte dog vente til 6.12.1909 før de første gang kom med ved en opvisning for offentligheden. Det hed herom i en af Vejles aviser:

„,Først viste foreningens kvindehold, ... en række forberedende øvelser, spring m.m. Der var almindelig begejstring og dygtig med håndklap, da damerne marcherede ud". (Avisens dato og navn er uoplyst.)

I starten efterlignede de kvindelige gymnaster blot mændenes præstationer (f.eks. i fritstående øvelser og spring), og derfor var de også med $i$,,konkurrencer" sammen med mandsholdene. D.v.s. kvinder som mænd blev efter opvisningerne talbedømt af dommere. Dette skete f.eks. ved den nævnte opvisning den 6.12.1909, og ved en opvisning den 26.3.1911. Disse ,,konkurrencer" blev dog opgivet i starten af 1920'erne. Baggrunden herfor var den tidligere omtalte selvstændiggørelse af den danske kvindegymnastik, hvor det blev forsøgt at lægge andre (æstetiske) kvaliteter ind i aktiviteterne end de traditionelle præstationsorienterede. Talbedømmelsen (og sammenligningen med mandsgymnastikken) stred imod denne udvikling og blev derfor opgivet. Mændene forstod som oftest ikke helt hvad der skete, hvilket bl.a. fremgik af VGF's festskrift fra 1938, hvor det om gymnastikken i 20 'erne hedder:

„,Det må så ganske givet blive herrerne, der i dette afsnit fører det store ord. Damernes præstationer er jo ikke lette at bedømme".

I det hele taget skete der en revolution med kvindegymnastikken i Vejle Gymnastik Forening i 20'erne. Der blev ansat nye lærere i kvindeafdelingen i 1926 (Hilda Jensen og Thora Hansen), som gennemforte de nye ideer om en selvstændig kvindegymnastik.

Samtidigt hermed, kunne der $i$ avisernes referater fra opvisningerne iagttages et skifte: Hvor man tidligere fokuserede på kvindernes yndefulde, men generelt svagere præstationer end mændenes, bedømte man fra omkring 1927 mere kvindegymnastikken på egne præmisser - og udfra om den levede op til forbilledet fra Snoghøj Kvindegymnastikhøjskole.

Disse forhold var uden tvivl stærkt medvirkende til, at kvinderne søgte til 
gymnastikken i stort tal, og fra vinteren 1926-27 var i flertal i VGF i forhold til mændene. Desuden begyndte flere af byens andre idrætsforeninger at optage kvindegymnastik på programmet, hvilket fremgår ved gennemgang af forhandlingsprotokoller m.m. fra disse. Den første forening til at tage tråden fra VGF op, var sandsynligvis Boldklubben Sport fra Grejsdalen, der den 4.12.1928 påbegyndte gymnastik for ,,voksne piger“ under Olga Borgs ledelse. Dernæst fulgte Vejle Idræts Forening med kvindegymnastik for vinteren 1931-32, hvorefter der i løbet af 1930'rne blev stiftet 3 nye foreninger med stor tilslutning fra kvindelige gymnaster: I 1934 Gymnastikforeningen Olympia og i 1936 Søndermarkens Gymnastikforening samt Gymnastikforeningen af 1936 (G.36).

Gymnastikken var hermed i Vejle - som den blev det på landsplan - blevet placeret som den største kvinde-idrætsgren; en placering, der er blevet fastholdt frem til vor tid. Hovedårsagerne til, at kvindegymnastikken forholdsvis hurtigt blev bredt accepteret, var sandsynligvis, at kvinderne under øvelserne kunne anvende ,,tækkelige klæder", og dermed ikke støde an mod den offentlige moral, samt at gymnastikken - specielt efter selvstændiggørelsen i midten af 1920'rne - ikke kunne anklages for at være ukvindelig. Anderledes forholdt det sig for kvindernes deltagelse i atletik.

\section{Kvindeatletik i Vejle Idræts Forening}

Som det er fremgået af oversigt 2, var der i København forskellige tidlige forsøg med kvindeatletik før DIF begyndte at anerkende danmarksrekorder $i$ 1930. Sådanne forsøg blev også gjort i Vejle Idræts Forening.

På Vejle Byhistoriske Arkiv findes et næsten komplet arkiv om VIF, med forhandlingsprotokoller, billeder, 2 jubilæumsskrifter m.m., så kvindeatletikkens udvikling i foreningen kan skitseres ret detaljeret.

I 1925 blev det på forårsgeneralforsamlingen i VIF vedtaget, at kvinder kunne blive medlemmer af foreningen. Der blev optaget $10 \mathrm{kvinder,} \mathrm{som}$ deltog i løb. Selv om de viste sig at løbe på ret gode tider, nåede de ikke at komme med i konkurrencer før forsøget blev opgivet samme år som det var startet. Årsagen hertil var af moralsk art: Mændene i VIF kunne ikke koncentrere sig om deres idræt når der var kvinder til stede på stadion under træningen! Samtidigt blev atletik - som bemærket tidligere - bestemt ikke anset for at være egnet for kvinder, så de første atletikpiger i Vejle havde store odds imod sig.

Men da DIF i 1930 begyndte at anerkende danmarksrekorder i kvindeatletik, var baggrunden for atter at få kvinder med i VIF blevet bedre. 


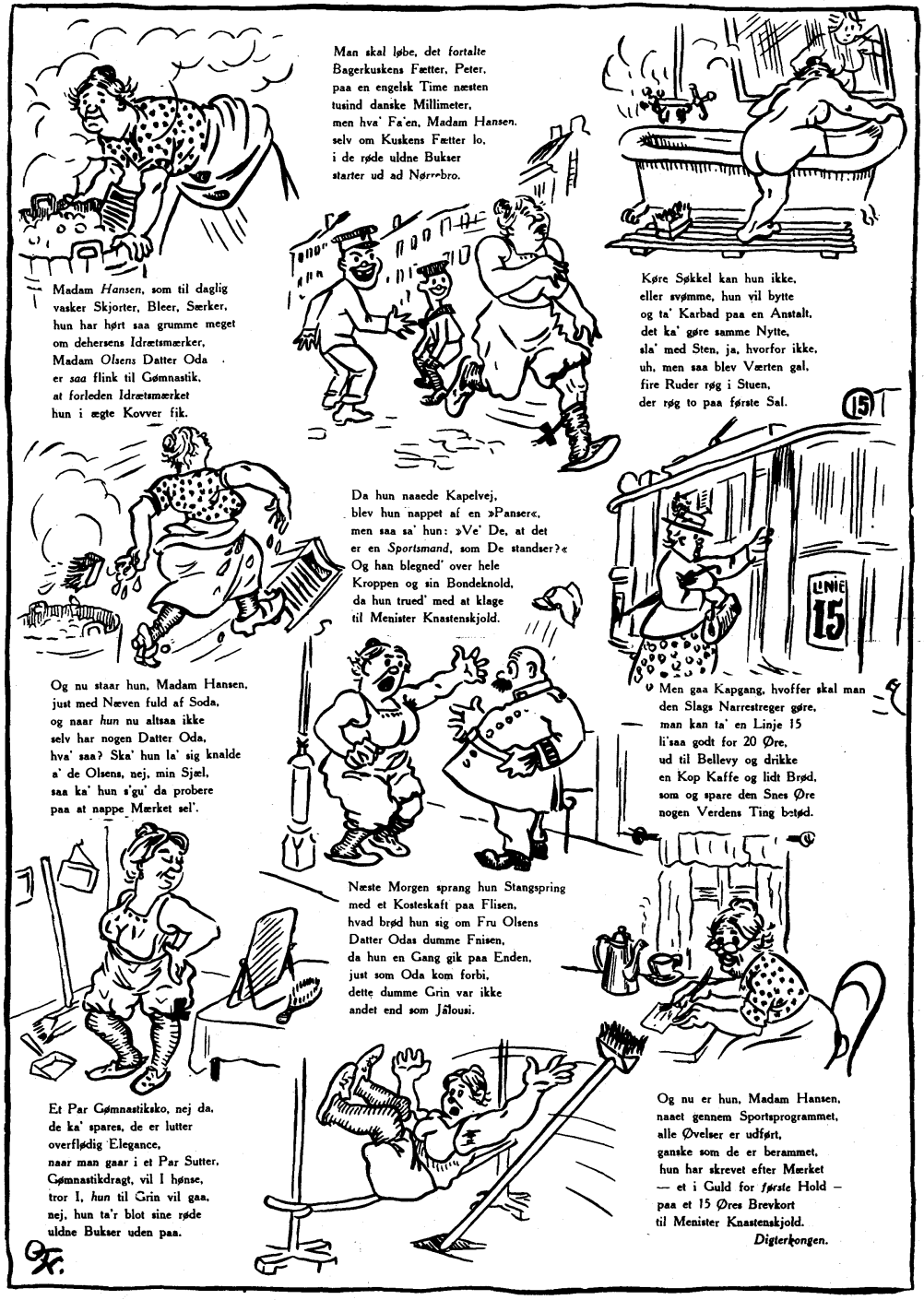

Idrætsmærket blev indstiftet i 1921. I 1922 fremkom denne vittighedstegning, der er tidstypisk for holdningen til kvindelige idrætsudøvere. Den fokuserer på de to områder: Påklædning og det ukvindelige. Blæksprutten skrev $i 1922$ om idrætskvinderne: „De havde alle gode ben, såfremt kommodeben kan kaldes gode ben “. 
Formanden for foreningen (Chr. Christensen) var, som vi tidligere har set, meget kritisk indstillet over for de første atletikkvinder i 1925, men han havde angiveligt siden den første fiasko kæmpet for at få kvindeatletikken tilbage i Vejle Idræts-Forening. Disse bestræbelser bar frugt under forårsgeneralforsamlingen i 1931, hvor det igen blev vedtaget at optage kvinder som aktive medlemmer.

Der blev i den første sæson optaget ca. 30 kvinder, hvoraf enkelte straks var med fremme i den danske elite og satte flere officielle danske rekorder.

En medvirkende årsag til, at det gik bedre end i 1925 var nok, at atletikkvinderne var "håndplukkede“. Kun kvinder, VIF's ledelse kunne acceptere, blev personligt opfordret til at melde sig ind $i$ foreningen. Desuden var modstanden mod kvinder inden for den mandsdominerede atletik ikke så voldsom (trods alt) som i 1925.

Selv om kvinderne derfor i 30'rne kunne bide sig fast i VIF og blive accepterede på idrætsbanen, så gik tolerancen dog ikke så langt, at de kunne få samme medlemsmæssige rettigheder som mændene. De to køn fik i Vejle Idræts-Forening først samme indflydelse på valg til bestyrelsen m.m. under 2. verdenskrig! (nærmere herom senere).

\section{0'rne: Gennembruddets årti for kvindeidrætten i Vejle}

1930'rne blev gennembruddets tid for idrætskvinderne i Vejle:

Efter forsøg med optagelse af kvindelige roere i Vejle Roklub i perioden 1919-25 (måtte opgives p.g.a. mangel på faciliteter), stiftede kvinderne selv en roklub i 1932, der hurtigt blev fast etableret. (Det er desværre ikke lykkedes at få adgang til denne forenings arkivalier, da de ikke er afleveret til arkivet i Vejle).

30'rne blev også kvindelige svømmeres gennembrudstid. Den første svømmeklub i Vejle blev startet i 1926, men det vides desværre ikke med bestemthed om der var kvinder med fra starten, da der ikke eksisterer noget arkiv om svømmeklubberne i Vejle. Vi er derfor henvist til at søge oplysninger i de lokale aviser. Heraf fremgår, at kvinderne i 30'rne udgjorde en stadig stigende del af de aktive medlemmer. Da ca. 40 utilfredse svømmere fra Vejle Svømmeklub stiftede en ny svømmeklub - Triton - i 1937, var en stor del af disse kvinder, og de fik ved stiftelsen valgt en repræsentant til en af de 4 bestyrelsesposter, samt en kvindelig revisor. (De to klubber blev i øvrigt sluttet sammen igen $i$ 1947).

Samme stigende omfang fik kvindernes deltagelse $i$ badminton og ridning $i$ 1930 'rne.

Vejle Rideklub blev stiftet i 1934 og havde fra starten en stor del kvindelige 
medlemmer, som havde dyrket sporten i nogle år forud for 1934. Kvinderne satte sig ved rideklubbens stiftelse på en af de 5 bestyrelsesposter. Vejle Badminton og Tennisklub blev stiftet $i$ 1935, med 80 senior-badminton spillere som medlemmer, hvoraf ca. 1/3 var kvinder. Desuden blev der spillet badminton - også for kvinder - i Boldklubben Sport i Grejsdalen fra vinteren 1932-33, fremgår det af denne forenings forhandlingsprotokoller.

Endelig var det også i 30'rne, at de første kvindelige håndboldspillere i Vejle viste sig.

Det fremgår af forhandlingsprotokollerne fra VIF, at kvinderne fra 1931 også dyrkede håndbold som afslutning på gymnastiktimerne. Efterhånden

greb spillet $\mathrm{i}$ foreningen om sig, så bestyrelsen på generalforsamlingen $\mathrm{i}$ 1934 måtte kritisere, at det var til skade for kvindernes atletikudøvelse, som ellers burde have 1. prioritet.

Foregangsklubben for kvindehåndbolden $i$ Vejle var dog Boldklubben Sport. Af klubbens protokoller fremgår, at det blev besluttet at starte en kvindehåndboldafdeling den 15.6.1936. (I øvrigt efter inspiration fra en opvisningskamp ved Sportsdagen den 9.6.1936 mellem piger fra Tørring og Hover).

Klubbens kvindehåndboldafdeling blev hurtigt en af de bedst organiserede i Vejle - og efter 2. verdenskrig også hjemsted for nogle af byens bedste spillere.

Et andet stort boldspil for kvinder, nemlig hockey, kendes der overhovedet ikke oplysninger om i Vejle før 2. verdenskrig, til trods for, at danmarksmesterskaber for kvindehold (som nævnt i oversigt 2) blev afholdt fra 1918.

Derimod var Vejle sensationelt tidligt på færde med forsøg på at inddrage kvinder i det bedst kendte boldspil i Danmark: Fodbold.

\section{Damefodbold i Vejle Boldklub}

Den sidste idrætsforening i Vejle, der skal omtales er Vejle Boldklub (VB). Der blev i efteråret 1984 afleveret et omfattende arkivmateriale til Vejle Byhistoriske arkiv, men dette er endnu ikke registreret og derfor (ligesom kendt materiale i privat besiddelse) ikke inddraget i denne artikel. Her ud over eksisterer der kun ét enkelt jubilæumsskrift om VB fra 1941. I dette skrift bliver det oplyst, at VB i 1906 på forårsgeneralforsamlingen vedtog, at kvinder kunne optages som medlemmer. Da Vejle Boldklub fra starten i 1891 udelukkende havde kricket og langbold på programmet, har det været nærliggende at antage, at det var en af disse to aktiviteter, kvinderne fik adgang til $i 1906$.

Ved gennemgang af tidens aviser, er det imidlertid konstateret, at det 
drejede sig om klubbens på det tidspunkt største aktivitet; fodbold. Det oplyses i avisernes generalforsamlingsreferater, at VB den 29.3.1906 vedtog at ændre lovene, i øvrigt med alle stemmer mod 1, så kvinder kunne optages som medlemmer, og hvis fremmødet var tilstrækkeligt, ville der blive oprettet et damefodboldhold!

VB placerede sig hermed som pionerklub frem for nogen hvad angår damefodbold i Danmark, idet der ikke kendes oplysninger om forsøg af den art på et så tidligt tidspunkt andre steder $\mathrm{i}$ landet. Der findes enkelte underretninger om forsøg med fodbold for kvinder i København i 1919, men fast etableret blev dame-fodbolden ikke før i slutningen af 1960'erne.

Vi kender desværre ikke meget til hvordan det gik med pionerindsatsen i Vejle Boldklub i 1906.

Sandsynligvis lykkedes det ikke at få vedtagelsen på generalforsamlingen ført ud i livet. I avisreferaterne fra de følgende generalforsamlinger omtales sagen i hvert tilfælde ikke eksplicit. Den eneste gang forsøget måske igen blev drøftet var på efterårsgeneralforsamlingen i 1906, hvor det af referaterne fremgår, at der , ,... behandledes under stigende interesse et par vigtige sager af foreløbig konfidentiel natur". Vejle Amts Avis 21.9.1906, side-2, sp. 4-5. Bag disse bemærkninger skjuler sig måske en diskussion af hvorfor damefodbolden ikke blev startet i Vejle Boldklub i 1906 - hvem ved?

Som afslutning på denne sensation i Vejles idrætshistorie skal bemærkes, at VB's love angående medlemsoptagelse ikke blev ændret tilbage til kun at tillade mænd, så det har faktisk siden 1906 været teoretisk muligt for kvinder at blive medlemmer af klubben.

Denne overraskende opdagelse er, som et naturligt led $\mathrm{i}$ det planlagte idrætshistoriske aktivitetscenters samarbejde med lokale idrætsforeninger, blevet meddelt Vejle Boldklubs ledelse. Dette bliver måske medvirkende til, at der nu optages kvinder $\mathrm{i}$ klubben. Der foregår nemlig i skrivende stund forhandlinger mellem Vejle Damefodboldklub og VB angående en sammenslutning - og pionerindsatsen i 1906 kan bruges som et argument for at gennemføre en sådan sammenslutning.

Det ser med andre ord ud til, at Vejle Boldklub vil optage damefodbold på programmet - med 80 års forsinkelse!

\section{Kvinder på ledelsesposter i Vejles idrætsforeninger}

Hvad angår kvindernes repræsentation i de forskellige idrætsforeningers bestyrelser, kan følgende svada i Vejle Gymnastik Forenings jubilæumsskrift fra 1938 stå som fuldt repræsentativ: 
„Vore kære damer følte sig ikke, og gør det heller ikke nu, som medlemmer af en forening. Når der var tale om generalforsamling og andre foreningen vigtige møder, så brillerede de ved deres fraværelse. Og det gør de desværre endnu“".

Udtalelsens bemærkninger om kvindernes manglende fremmøde er fuldt korrekte, men samtidigt er den manglende forståelse for kvindernes situation også tidstypisk for idrætsmændenes holdning i perioden. Det var jo (er jo?) svært for mange kvinder at ,føle sig som medlemmer af en forening", d.v.s. møde fast frem til generalforsamlinger og lign., når det traditionelle kønsrollemønster pålagde kvinderne det fulde ansvar for de huslige pligter. Derfor er det ikke overraskende at så få kvinder gjorde sig gældende på ledelsesposter i Vejles idrætsforeninger før 2. verdenskrig - og at de få, der bemærkes, næsten alle var ugifte!

Den første idrætsforening i Vejle, der fik kvinder valgt i bestyrelsen var uden tvivl Vejle Lawn Tennisklub, der ved stiftelsen i 1900 tildelte kvinderne 2 ud af 5 bestyrelsesposter. Det er dog karakteristisk for kvindernes indflydelse, at de 3 mænd fordelte de betydende poster som formand, kasserer og sekretær imellem sig.

Det var desuden karakteristisk, at de to kvinder (frk. J. Bjerregaard og frk. J. Brincker) hurtigt trak sig ud af bestyrelsen, da der viste sig egnede mænd og at den næste kvinde først blev valgt $\mathrm{i} 1925$.

Vejle Gymnastik Forening var også - som gymnastikforeningerne generelt i Danmark - en af de første foreninger med kvinder i bestyrelsen. Allerede i 1913 er der sikre oplysninger om den første kvinde (frk. Mølgaard) i VGF's bestyrelse.

Desuden blev kvindegymnastikken i foreningen altid ledet af en kvinde. Det normale inden for idrætten har ellers altid været, at selve træningen blev varetaget af mændene - men her danner gymnastikken altså også en undtagelse.

Udover tennis og gymnastik er det ikke lykkedes at finde eksempler på andre bestyrelsesposter til kvinderne, før i gennembruddets årti; 1930'rne.

I denne periode blev det derimod almindeligt med enkelte kvinder $i$ bestyrelserne for de foreninger, hvor de udgjorde en større del af medlemmerne. F.eks. i ridning, svømning og badminton.

Inden for gymnastik (Søndermarkens Gymnastikforening) og naturligvis roning (Damernes Roklub), opnåede de endda at beklæde de betydende poster som formand og kasserer. Kvinderne havde dog stadig store problemer med at blive accepterede på lige fod med mændene. Som tidligere nævnt har disse problemer holdt sig til i dag, hvor kvinderne stadig som oftest trænes af mænd, og ledelsesposterne (specielt på højere niveau inden 
for idrættens organisationer) stadig overvejende beklædes af mænd.

De færreste steder har man dog gennemført decideret forskelsbehandling mellem mænd og kvinder gennem vedtagne love, men dette skete i Vejle Idræts-Forening i perioden 1931 til omkring 1944.

Som nævnt optog. VIF kvindeatletik på programmet i 1931, og omkring samme tidspunkt gymnastik og håndbold for kvinder, men disse kvindelige medlemmer fik først stemmeret på foreningens generalforsamlinger i 1932. Der var endvidere tale om en begrænset stemmeret, som fik forskellig udformning i lovene, men meningen, som den fremstod af diskussionerne refereret i foreningens forhandlingsprotokoller, var klar nok: Kvinderne var at betragte som en underafdeling i (og mindre vigtig del af) VIF.

Følgende paragraffer var gældende $i$ foreningen fra 1937 og frem til fuld medlemsmæssig ligestilling blev gennemført i 1944:

„§14. Ved valg til bestyrelsen kan de mandlige bestyrelsesmedlemmer kun vælges af herrer, mens de kvindelige bestyrelsesmedlemmer kun kan vælges af damer. I alle andre tilfælde hvor der kan blive tale om stemmeafgivning har damer og herrer lige stemmeret.

§15. Bestyrelsen består af 7 mandlige medlemmer: Formand, næstformand, kasserer, sekretær og 3 bestyrelsesmedlemmer samt 2 kvindelige medlemmer".

Kvinderne kunne altså kun vælge 2 medlemmer til bestyrelsen - og disse to kunne endda kun blive ordinære medlemmer af denne! Denne begrænsede indflydelse var sandsynligvis medvirkende til, at kvinderne blev accepteret af mændene i 1931, hvad formanden Chr. Christensen også var inde på i et tidligere omtalt jubilæumsinterview i 1932. Angående medtagelsen af de nye kvindelige medlemmer i 1931 sagde han:

„De unge mennesker var jo bange for, at pigebørnene skulle lave helt om på foreningen og dens love. Men det viste sig da efterhånden at være ubegrundet mistanke“.

Her er vi nok desværre fremme ved hovedpointen: De første idrætskvinder i Vejle kunne accepteres, hvis de ville dyrke idræt som mændene gennem mange år havde tilrettelagt det - og på en måde som tilfredsstillede den almindelige opfattelse af hvad kvinder kunne - og måtte.

Kun gymnastikken - og til en vis grad roningen fra 1932 - skilte sig ud, som områder hvor kvinderne hurtigt tog sagerne i egne hænder, og selv fastlagde præmisserne for deres idrætsaktivitet.

Alt i alt kan det konkluderes, at de første enkelte idrætskvinder i Vejle var 
skøjteløbere og tennisspillere - samt at gymnastikken i VGF stod for den første fast etablerede kvindeidræt af større omfang. Dette stemmer udmærket med de generelle danske tendenser, som de fremgår af oversigt $1+2$. Kvinderne i Vejle var derimod sent på færde i håndbold, og tidligt ude med atletik (VIF 1925), samt måske fodbold (VB 1906). I disse to tidlige tilfælde skete der dog ikke noget gennembrud i første omgang. 
